\title{
PERFIL DOS TRABALHADORES TERCEIRIZADOS NO BRASIL ${ }^{1}$
}

\author{
PROFILE OF THIRD PARTY WORKERS IN BRAZIL
}

\author{
Francisco Demetrius Monteiro Rodrigues ${ }^{2}$ \\ José Márcio dos Santos ${ }^{3}$ \\ Priscila de Souza Silva ${ }^{4}$
}

\begin{abstract}
RESUMO
O principal objetivo deste estudo é traçar o perfil sociodemográfico e socioeconômico dos trabalhadores terceirizados no mercado de trabalho formal brasileiro durante os anos de 2006 e 2018. Para tanto, a principal fonte de dados é a Relação Anual de Informações Sociais (Rais) do Ministério do Trabalho e Emprego (MTE). Os principais resultados do estudo mostram aumento expressivo do número de trabalhadores terceirizados entre 2006 a 2018. Quanto ao perfil dos terceirizados, esses são majoritariamente do sexo masculino, têm entre 30 a 39 anos de idade, cursaram do ensino médio completo até o superior incompleto, permaneceram menos de um ano no mesmo emprego e auferem entre um e dois salários mínimos.
\end{abstract}

Palavras-chave: terceirização, trabalho, Brasil.

\begin{abstract}
The main objective of this study is to outline the sociodemographic and socioeconomic profile of outsourced workers in the Brazilian formal labor market, during the years 2006 and 2018. For this purpose, the main source of data is the Annual List of Social Information (Rais) of the Ministry of Labor and Employment (MTE). The main results of the study show a significant increase in the number of outsourced workers between 2006 to 2018. As for the profile of outsourced workers, these are mostly male, between 30 and 39 years of old, attended high school through incomplete higher education, they stayed less than a year in the same job and earn between one and two minimum wages.
\end{abstract}

Keywords: outsourcing, job, Brazil.

\section{JEL Classification: J81}

\section{INTRODUÇÃO}

Diariamente, difundem-se na sociedade os inúmeros benefícios econômicos, as diversas estratégias de eficiência e os ganhos de competitividade que as atividades terceirizadas

\footnotetext{
O presente trabalho foi realizado com apoio da Coordenação de Aperfeiçoamento de Pessoal de Nível Superior Brasil (Capes) - Código de Financiamento 001.

2 Mestrando em Demografia pelo Programa de Pós-Graduação em Demografia da Universidade Federal do Rio Grande do Norte (PPGDEM/UFRN). Pesquisador do Observatório das Migrações no Estado do Ceará. E-mail: demetriusmonteiro85@gmail.com.

3 Professor assistente da Universidade Regional do Cariri (URCA). Doutorando em Economia pela Universidade Federal Fluminense. E-mail: jmarcio.santos@hotmail.com.

${ }^{4}$ Doutoranda em Demografia pelo Programa de Pós-Graduação em Demografia da Universidade Federal do Rio Grande do Norte (PPGDEM/UFRN). Pesquisadora do Observatório das Migrações no Estado do Ceará. E-mail: pryscila.souzas@hotmail.com.
} 
propiciam tanto no setor privado como no público. Em decorrência disso, a terceirização se tornou um assunto muito polêmico, já que para alguns ela pode gerar irregularidades trabalhistas que agudizam a precarização do trabalho e para outros é uma medida eficaz para a contenção de custos com mão de obra, de ganhos de eficácia e produtividade (GIOSA, 1997; HUME, 2009; SEVERO, 2015).

Dessa maneira, a terceirização constitui tema relevante de estudo, pois como qualquer fenômeno passível de observação, tal estratégia administrativa promove alteração no cenário das relações humanas, uma vez que constitui instrumento de interação social e profissional que repercute em novas relações de trabalho. Assim, as prerrogativas decorrentes da terceirização do trabalho estimularam a elaboração deste estudo, pois além de ser um tema atual torna-se relevante ao atingir diretamente milhões de trabalhadores no cenário político, econômico e social. Nesse contexto, o intuito deste estudo é responder ao seguinte questionamento: quem são os trabalhadores terceirizados no mercado de trabalho formal brasileiro?

Diante do exposto, este trabalho se justifica por ampliar os conhecimentos a respeito do processo de terceirização e por tratar de uma temática de grande interesse científico, suscetível de descrição. Isso porque, em geral, as pesquisas que relatam a temática da terceirização são incipientes quanto às características dos trabalhadores terceirizados, afetados diariamente pela dinâmica do mercado de trabalho e por todos os processos organizacionais adotados.

Assim, o principal objetivo deste estudo é traçar o perfil sociodemográfico e socioeconômico dos trabalhadores terceirizados no mercado de trabalho formal brasileiro durante os anos de 2006 e 2018. Para alcance do objetivo proposto, em termos quantitativos a principal fonte de informações são os dados da Relação Anual de Informações Sociais (Rais) do Ministério do Trabalho e Emprego (MTE).

No que diz respeito à estrutura deste artigo, além desta introdução, a segunda parte revisa estudos sobre a terceirização do trabalho. A terceira descreve a recente regulamentação do trabalho terceirizado no Brasil. A quarta apresenta os procedimentos metodológicos. A quinta traça o perfil sociodemográfico e socioeconômico dos trabalhadores terceirizados no mercado de trabalho formal brasileiro. Por fim, apresentam-se as considerações finais.

\section{DEBATE CONCEITUAL SOBRE A TERCEIRIZAÇÃO DO TRABALHO}

O principal objetivo desta seção é revisar estudos sobre a terceirização do trabalho a fim de aprofundar o debate acerca desse tema no mercado de trabalho brasileiro, de diferentes perspectivas, no que se refere a conceitos, definições e as principais vantagens e desvantagens da terceirização.

Giosa afirma que a terceirização consiste em uma técnica moderna da administração que transforma a estrutura, os processos de gestão e os sistemas das empresas. Ressalta que a técnica é adotada com objetivo explícito de "[...] atingir melhores resultados, concentrando todos os esforços e energia da empresa para a sua atividade principal" (1997, p. 11).

Oliveira (1998) ressalta que se busca na terceirização maior agilidade dos serviços prestados, com tônica na redução dos custos operacionais, e afirma que no setor privado o ente público terá mais tempo para a excelência do produto. Além disso, quando se contratam empresas terceiras para prestação de serviços, um leque de oportunidades se abre para concorrência e competitividade, refletindo na qualidade e no preço dos serviços no mercado consumidor. 
Em um estudo sobre o processo de terceirização do trabalho na Bahia, realizado entre as décadas de 1990 e 2000, Druck e Borges (2002) discutem que a terceirização pode ser definida como instrumento de gestão e organização do trabalho, porquanto propaga a flexibilização, à medida que transfere para terceiros os custos trabalhistas. Os achados referentes a uma pesquisa realizada em uma indústria petroquímica mostram que na visão empresarial, as principais vantagens da terceirização remetem à redução dos custos e de pessoal. No entanto, entre as desvantagens, a pesquisa aponta despreparo dos terceirizados, perda de habilidade técnica, problemas de natureza sindical, entre outros. No que se refere aos trabalhadores terceirizados, as principais reivindicações remetem à precarização do trabalho. Desse modo, constatam que as marcas da terceirização são precarização, perda de direitos, instabilidade e insegurança nas relações de trabalho.

Delgado (2003) conceitua terceirização como uma estratégia de descentralização das atividades de uma empresa, que são repassadas para outrem (terceiro). Enfatiza em seu estudo que o fenômeno promove uma relação trilateral entre as partes, dissociando assim as relações jus trabalhistas, haja vista que o empregado terceirizado não tem nenhum vínculo formal com a tomadora de serviço.

Para o Departamento Intersindical de Estatística e Estudos Socioeconômicos (DIEESE, 2003), a prática da terceirização consiste na transferência de uma e/ou mais atividades secundárias, que antes eram executadas pelos ocupantes do quadro de funcionários de uma instituição, a uma prestadora de serviços contratada. Salienta este que os trabalhadores fazem parte do processo de terceirização, mas o que é terceirizado são as atividades contratadas. Segundo o estudo, as principais justificativas adotadas pelas empresas para adotar a terceirização são: aumento das inovações organizacionais, vantagem competitiva, redução dos custos, simplificação dos processos administrativos, maior eficiência e aumento da produtividade e qualidade. Entretanto, para os trabalhadores a conjuntura é distinta: ocorre redução dos rendimentos, perda de emprego e precarização do trabalho.

Fróes (2003), em seu estudo sobre a terceirização, relata que esse processo não é uma experiência nova no Brasil e constitui uma abordagem estratégica para contenção de custos, maior produtividade, qualidade e poder competitivo que propaga acesso às novas tecnologias e concentração nas atividades de maior retorno para as empresas. Nesse sentido, define a terceirização como um processo de transferência de atividades para terceiros que aglutina duas etapas, a saber: desativação de setores da instituição; contratação de terceiros para a prestação de serviços e/ou atividades. Os principais objetivos almejados com a terceirização perfazem redução de custos, focalização, acesso a novas tecnologias e ganho de qualidade. No entanto, o padrão da terceirização caracteriza-se pela redução dos custos, calcado em exploração e precarização da mão de obra.

De acordo com Imhoff e Mortari (2005), a terceirização consiste na transferência de tarefas cujo custo/benefício não é vantajoso para a empresa. Nessa óptica, as principais atividades terceirizadas são as de apoio, tais como: limpeza, alimentação de funcionários, assistência médica e jurídica, contábeis, entre outras. Na perspectiva dos autores, o fenômeno gera a criação de novas empresas para a prestação de serviços, e consequentemente promissoras novas vagas de emprego. Todavia, advertem que um dos principais riscos decorrentes da terceirização é a contratação de empresas sem idoneidade, competência e qualificação para a prestação dos serviços, o que acaba por gerar problemas de ordem trabalhista. Ademais, quando o mecanismo é adotado visando apenas à redução de custos e a meta não é atingida ocorre desprestígio socioeconômico de todo o processo. 
Silva (2005), centrado nas relações de trabalho, afirma que a técnica da terceirização, tida como subcontratação e amplamente difundida pelo mundo, antes de qualquer coisa significa precarização das relações de trabalho, e implica, sobretudo, redução da seguridade social. Nessa óptica, Russo e Leitão (2006), em estudo desconstrutivista sobre a terceirização, relatam que a técnica nada mais é do que uma estratégia mercantil com propósito de obter apenas vantagem instrumental-econômica. Além disso, eles concluem que sob nenhum aspecto a terceirização está preocupada com o bem-estar dos trabalhadores e/ou a qualidade dos postos criados.

Por sua vez, Brisola e Oliveira (2008) enfatizam que na era da globalização a terceirização deveria ser uma aliada das empresas, do governo e dos trabalhadores. Quando bem administrada, ela fornece produtos e/ou serviços prestados por pessoal especializado. No entanto, ela também imputa muitos aspectos negativos. Os autores chamam atenção para o fato de que na prática a terceirização do trabalho não tem sido difundida para ganhos de eficiência e aperfeiçoamento da prestação de serviços, mas tem sido empregada para burlar a exigência de concursos públicos e realizar fraudes. Ademais, quando se opta pela terceirização de certas atividades, as empresas não passam por critérios rigorosos de seleção - que considerem honradez, idoneidade, responsabilidade social e trabalhista - nem mesmo por critérios simples, como o risco de insolvência, "[...] mas sim pelo único parâmetro considerado inadequado a uma ‘boa terceirização' que é o parâmetro do menor custo” (SILVA, 2012, p. 7).

Os estudos de Hume (2009) e Oliveira (2009) definem a terceirização como uma estratégia econômica de parceria na qual o labor terceirizado propicia redução de custos e aperfeiçoamento das atividades que não constituem o foco principal da empresa contratante. Dentre os principais benefícios da adoção da terceirização no mercado de trabalho, destacam-se maior agilidade na tomada de decisões, menor burocratização, obtenção de serviços de qualidade superior, redução do imobilizado, liberação de espaço físico, formalização de parcerias e valorização profisssional.

Em contrapartida, segundo Carmo (2011) a terceirização é um novo modelo econômico que só favorece os capitalistas. Apesar de proporcionar maior agilidade, flexibilidade e competitividade no mercado, ela precariza os direitos trabalhistas, dado que os trabalhadores sob a condição de terceirizados não mantêm vínculos empregatícios com a instituição contratante, mas com a prestadora de serviço.

Para Marcelino e Cavalcante, "a terceirização é todo processo de contratação de trabalhadores por empresa interposta, cujo objetivo último é a redução de custos com a força de trabalho e (ou) a externalização dos conflitos trabalhistas" (2012, p. 331). Dessa forma, argumentam que a terceirização constitui importante recurso estratégico para redução de custos, no entanto, em vista do contexto histórico brasileiro, o processo torna-se indissociável da ampliação da precarização do trabalho, porquanto na prática a respectiva estratégia é empregada substancialmente com a finalidade de transferir para terceiros os "problemas trabalhistas", os riscos e partes dos custos.

Fernandes e Lara (2013) definem a terceirização como um mal necessário para o bom desempenho da economia. Para os autores, essa estratégia acrescenta qualidade e produtividade, pois consiste na contratação de serviços que serão prestados de forma mais eficiente e com custo reduzido. Adicionalmente, os autores ressaltam que as empresas que aderem à terceirização das atividades acessórias recebem resultados satisfatórios, sem nenhuma obrigação trabalhista com os empregados da prestadora contratada.

Em seus estudos sobre a terceirização do trabalho, Antunes e Druck $(2013 ; 2015)$ constataram que respectiva estratégia de gestão, organização e controle constitui fio condutor 
para a exploração, precarização e corrosão do trabalho no Brasil. Isso porque a terceirização fragmenta e desmembra as unidades coletivas, sindicais e de luta, atua como ferramenta de discriminação e desvalorização dos trabalhadores e perfaz instrumento facilitador para burlar a legislação trabalhista e social. Além disso, os autores evidenciaram que os trabalhadores terceirizados auferem menores rendimentos quando comparados aos demais empregados contratados, ao mesmo tempo em que apresentam elevada jornada de trabalho e rotatividade. Quanto às condições de segurança, Antunes e Druck observaram que os terceirizados, por estarem mais expostos aos riscos, padecem de maior número de acidentes de trabalho. Achados ratificam a condição mais precária e vulnerável dos terceirizados.

Nessa perspectiva, o estudo de Druck e Filgueiras (2014) apresenta a terceirização como uma modalidade de gestão que impõe flexibilização e precarização ao trabalho. Assim, embora a principal consequência do processo seja a corrosão do trabalho, o discurso de modernização, especialização e foco nas atividades centrais das instituições ainda sustenta a prática da terceirização. No entanto, evidenciam os autores que a terceirização resulta em maior rotatividade, salários mais baixos, contratos flexíveis e fragmentação coletiva e de sindicatos, ao mesmo tempo em que potencializa a exploração dos trabalhadores. Desse modo, Druck e Filgueiras enfatizam que a terceirização constitui um problema social no país porque expõe os trabalhadores a situações de degradação, desvalorização e discriminação análogas ao trabalho escravo.

Meireles, por sua vez, define terceirização como uma prática empresarial de centralização dos esforços na função central do negócio: o lucro. O autor ressalta que a empresa tomadora de serviço terceirizado deixa "[...] a cargo da contratada todas as responsabilidades que envolvem a prestação de serviços, como seleção, admissão, treinamentos e acompanhamentos [...]" (2014, p. 9), ações fundamentais para a contratação de trabalhadores capacitados.

Biavaschi e Teixeira (2015) compreendem o fenômeno da terceirização como expressão da dinâmica capitalista de produção. Desse modo, ela constitui uma modalidade de contratação que precariza as relações de trabalho, aprofunda as desigualdades e fragmenta o poder de organização da classe trabalhadora. As autoras defendem que apesar do discurso de especialização do trabalho e de aumento da competitividade e produtividade, na prática o principal indutor das iniciativas de terceirização é a redução dos custos.

Campos (2015) aprofunda esse debate ao afirmar que explicitamente a terceirização propaga o enfraquecimento dos direitos trabalhistas, pois com ela se torna cada vez mais difícil sindicalizar e mobilizar os empregados. Em segundo lugar, nem sempre todas as empresas que prestam serviços terceirizados são organizadas e capazes de cumprir com todas as obrigações trabalhistas, o que deveria ser a maior restrição contra o fenômeno, porquanto o mesmo deixa o trabalhador à margem do processo.

Severo (2016) argumenta em seu estudo que na prática a terceirização gera efeitos perversos tanto para o trabalhador como para a sociedade. Isso porque propicia a figura de atravessadores, entes interpostos que negociam a prestação do trabalho do empregado e reduzem seu valor. São milhares de trabalhadores no Brasil que se submetem a exaustivas jornadas de trabalho sem segurança, simplesmente porque as oportunidades de emprego digno estão sucumbindo à ganância do capitalismo. $\mathrm{O}$ autor corrobora suas afirmativas demonstrando, por meio de estudos do Dieese e da CUT, que $80,7 \%$ das mortes por acidente de trabalho são de empregados terceirizados, ou seja, a cada dez acidentes fatais oito envolvem trabalhadores terceirizados. Ademais, destaca que a terceirização nos impede de exigir serviços públicos e privados de qualidade, afinal o sistema paga para que outros realizem suas obrigações. 
Por meio dessa revisão bibliográfica, sob a óptica de diferentes argumentações, constatamos que a terceirização propaga a redução de custos e os ganhos de competitividade e eficiência, mas é associada à precarização das relações de trabalho. Nessa perspectiva, segundo alguns estudiosos ela provoca, sobretudo, perda da identidade cultural por parte dos funcionários, que por estarem instáveis emocional e financeiramente não têm motivação para o trabalho, o que acarreta queda da produtividade. Consequentemente, o mecanismo já não tem nenhum sentido (DRUCK; BORGES, 2002; DRUCK; GODINHO, 2003; HUME, 2009; IMHOFF; MORTARI, 2005; OLIVEIRA, 2009; SEVERO, 2015).

\section{A REGULAMENTAÇÃO ÀS ESCURAS DO TRABALHO TERCEIRIZADO NO BRASIL}

Partindo de todo um viés histórico e socioeconômico, constatamos que a terceirização, tanto no setor público quanto no privado, adentrou no país e continua se perpetuando, essencialmente, por causa do discurso de contenção de gastos. Nesse sentido, as instituições terceirizam basicamente para reduzir custos com encargos trabalhistas, com a premissa peculiar de que, transferindo para terceiros suas atividades de suporte - não tão dependentes da atividade central - poderão aprimorar e focar melhor na sua missão, seja ela proporcionar para todos saúde, educação e segurança, seja produzir bens e serviços variados (SILVA, 2012).

Desse modo, a terceirização desmedida espalha-se nos mais distintos segmentos econômicos brasileiros. Como um fato social polêmico, o fenômeno toma proporções desenfreadas: há professores terceirizados em escolas e motoristas em empresas de transporte, não existindo distinção entre a atividade-fim e atividade-meio nas instituições. E quem mais sofre são os trabalhadores, que estabelecem relações empregatícias precárias (SEVERO, 2016).

Nesse sentido, iniciou-se um movimento que culminou na tentativa peculiar do governo em regulamentar a terceirização. Ora fomentando e ora freando o processo perante opiniões tão ambíguas, jurisprudencialmente o debate iniciou com o Projeto de Lei (PL) n. ${ }^{\circ} 4.330$ - I, de 2004, que dispõe sobre os contratos e as relações de trabalho decorrentes da terceirização. A proposta, bastante extensa, aplicava-se exclusivamente às empresas privadas, excluindo o âmbito da administração pública. Todavia, incluía as empresas estatais que faziam amplo uso da terceirização. Além disso, o projeto definia regras para a terceirização, a saber: quais empresas podiam dela participar (contratantes e contratadas, especializadas em um serviço singular com qualificação técnica e capacidade econômica compatível com a prestação do serviço) e o tipo de trabalhador que poderia ser contratado, ou seja, apenas os assalariados (CAMPOS, 2015).

Posteriormente, o projeto foi encaminhado ao Senado, com a denominação de Projeto de Lei da Câmara (PLC) n. ${ }^{\circ}$ 30/2015. Substancialmente, ele permitia a prática da terceirização em todas as atividades da empresa, incitando-a de forma discriminada e sem responsabilidade social (SEVERO, 2016). Nesse contexto, a PLC n. ${ }^{\circ} 30 / 2015$ poderia chancelar o maior retrocesso experimentando no mercado de trabalho brasileiro. Extremamente nociva no ambiente de trabalho, ela instaurava a fragmentação da luta comum, potencializava a capacidade de exploração e intrinsecamente reduzia a atuação dos agentes - sindicatos -, que impõem limites às piores condições de trabalho (CAMPOS, 2015; LIMA, 2010; SEVERO, 2016; SOUSA et al, 2013).

Em meio a tantos questionamentos sociais sobre a efetividade e os relevantes malefícios advindos da aprovação da PLC n. ${ }^{\circ}$ 30/2015 foi criada uma alternativa ao projeto supracitado, o Projeto de Lei do Senado (PLS) n. ${ }^{\circ}$ 300, de 2015, que estabelecia a responsabilidade solidária 
da contratante sob as verbas trabalhistas e previdenciárias, vedava a continuidade da contagem do período aquisitivo ou a fruição das férias em casos de terceirização sucessiva, estabelecia as condições de segurança, higiene e salubridade dos empregados da contratada, entre outras medidas (BRASIL, 2015).

Todavia, a referida proposta, mais paliativa para regulamentar o processo de terceirização, foi engavetada, e o Presidente Michel Temer e sua base aliada implementaram ao Substitutivo do Senado o Projeto de Lei n. ${ }^{\circ}$ 4.302-E de 1998, proposto pelo Governo Fernando Henrique Cardoso, que já fora aprovado com modificações pelo Senado no ano de 2002 e pela Câmara em 2016. Peculiarmente, o respectivo entrou em pauta no Congresso Federal em de 21 de março de 2017, tendo 231 votos a favor, 188 contra e 8 abstenções, sendo aprovado no dia 22 de março de 2017 (MENDONÇA; ALESSI, 2017).

A prenunciar, o projeto chancela a terceirização em quaisquer atividades da empresa, não se restringindo às atividades-meio das instituições. Além disso, não prevê a garantia dos direitos previdenciários, tampouco a responsabilidade solidária do contratante. A proposta aprovada foi sancionada parcialmente no dia 31 de março de 2017 pelo Presidente Michel Temer e publicada em edição extra do Diário Oficial da União sob a forma da Lei n. ${ }^{0}$ 13.429/2017, que dispõe sobre o trabalho temporário e a prestação de serviços terceirizados (BRASIL, 1998).

Na visão dos que criticam a medida, a nova legislação incentivará a demissão em massa de trabalhadores sob o regime de CLT e culminará na contratação desenfreada de terceiros. Já os argumentos dos que apoiam o projeto se baseiam nas premissas de aumento da especialização, da produtividade e de expansão do emprego. Todavia, o que se sabe ao certo é que muito ainda deveria ser discutido antes de qualquer medida paliativa. Ademais, ressalta-se a necessidade de barrar projetos tão antigos e desatualizados como esse que foi sancionado às escuras e que não atende aos debates democráticos e às demandas sociais por mais equidade.

Em suma, a terceirização constitui tema extremamente oportuno no contexto atual. Além de despertar inúmeras discussões contrárias e favoráveis ao processo, ela desperta curiosidade, pois afeta diretamente a vida de milhões de trabalhadores que se submetem a esse regime de emprego. Diante do exposto, a principal contribuição deste estudo será traçar o perfil dos trabalhadores terceirizados no mercado de trabalho formal brasileiro.

\section{PROCEDIMENTOS METODOLÓGICOS}

\subsection{Fontes de dados, recorte temporal e geográfico}

A principal fonte de informações são os dados da Relação Anual de Informações Sociais (Rais) do Ministério do Trabalho e Emprego (MTE). A Rais constitui uma das principais fontes de informação acerca do mercado de trabalho formal brasileiro. Instituída pelo Decreto n. ${ }^{\circ} 76.900$, de 23 de dezembro de 1975, ela visa suprir as necessidades de controle, de estatísticas e de informações das entidades governamentais da área social. Importante instrumento de gestão governamental, constitui insumo para o cumprimento das normas legais trabalhistas, de controle dos registros e benefícios previdenciários. Adicionalmente, é utilizada na elaboração de políticas públicas de combate às desigualdades de emprego e renda.

A Rais compreende $97 \%$ do universo do mercado de trabalho formal, abrangendo geograficamente todo o território nacional e a natureza de seu levantamento de registro administrativo tem periodicidade anual. Os dados extraídos indicam o estoque (número de empregos) de trabalhadores formais em determinado ano-base anterior e a movimentação da mão de obra empregada (admissões e desligamentos). 
Nesse ensejo, é oportuno destacar que, apesar da vasta disponibilidade de bases de dados sobre o mercado de trabalho no Brasil, as informações para identificar com clareza e precisão os trabalhadores terceirizados não estão disponíveis para acesso público. Mediante essa restrição, a Rais tem sido frequentemente utilizada por pesquisadores nos estudos sobre terceirização. No entanto, respectiva fonte de dados não permite identificar se determinado trabalhador atua ou não como terceirizado. Ainda assim, a Rais possibilita empregar distintas abordagens metodológicas para compreender o fenômeno da terceirização, assim como analisar as características dos trabalhadores que se submetem à labuta terceirizada (PELATIERI et al., 2018a; REBELO et al., 2018).

Quanto ao recorte temporal do estudo, os anos são 2006, primeiro ano de divulgação dos dados relativos à mão de obra terceirizada, e 2018, ano de divulgação mais recente da Rais. No tocante ao recorte geográfico, a análise é para o Brasil, dado que se tem como objetivo ampliar o conhecimento a respeito do trabalho terceirizado em um país com dimensões continentais. Além disso, o motivo da escolha desse lócus de estudo foi devido à quase inexistência de pesquisas sobre o perfil sociodemográfico e socioeconômico dos trabalhadores terceirizados no país.

\subsection{Conceitos}

Por reconhecer que a dimensão política e social da terceirização e das relações de trabalho estabelecidas são indissociáveis da exploração da mão de obra e da premissa de redução de custos, neste estudo adota-se o conceito proposto por Marcelino e Cavalcante, que definem:

[...] terceirização é todo processo de contratação de trabalhadores por empresa interposta, cujo objetivo último é a redução de custos com a força de trabalho e/ou a externalização dos conflitos trabalhistas. Ou seja, é a relação na qual o trabalho é realizado para uma empresa, mas contratado de maneira imediata por outra (2012, p. 338).

A literatura aponta que a terceirização constitui poderoso instrumento para ampliação da precarização do trabalho, à medida que na prática é adotada com objetivo de transferir os "problemas" de ordem trabalhista e assim reduzir custos. Nesse ensejo, é oportuno conceituar o que se entende por precarização do trabalho: processo que intensifica as desvantagens nas condições de trabalho. Nesse sentido, trabalhos precários são aqueles que percebem menores salários, menor tempo de emprego, maior rotatividade, maior jornada de trabalho e desproteção contratual, causam maior insegurança no trabalho e nos quais os direitos trabalhistas podem ser facilmente contornados (ANTUNES, 2015; CARVALHO; BRIDI, 2015; DRUCK, 2007; PELATIERI et al., 2018b).

Os demais conceitos adotados neste artigo seguem as definições que constam na documentação da Rais:

Trabalhadores formais: qualquer ocupação trabalhista, manual ou intelectual, com benefícios e carteira profissional assinada. Trata-se de trabalho fornecido por uma empresa, com todos os direitos legais garantidos. O papel ocupado ou a função que a pessoa desempenha em alguma atividade econômica lhe confere uma remuneração.

Remuneração (ou rendimento): paga ou não, importa a competência mensal, que dá ao empregado o direito de recebê-la, independentemente do momento em que se tenham repassado ao empregado tais valores (2016, p. 29-41). 


\subsection{Variáveis}

Para fins metodológicos, os setores verificados na Classificação Nacional de Atividades Econômicas (CNAE), extraídos da Rais, foram agregados com base na categorização empregada por Rebelo et al. (2018, p. 69-76). Tais autores listaram os setores econômicos em dois grupos: terceirizados e contratantes. Neste estudo foram considerados os setores classificados como terceirizados, que de acordo com diferentes perspectivas tratam de atividades tipicamente terceirizadas (CUT, 2014; PELATIERI et al., 2018a; 2018b; SOUSA; SOBRAL; MACAMBIRA, 2018).

Desse modo, algumas atividades classificadas como terceirizadas foram: locação de mão de obra temporária; fornecimento e gestão de recursos humanos para terceiros; seleção e agenciamento de mão de obra; atividades de apoio, manutenção e reparação; atividades relacionadas à reparação; atividades de limpeza; atividades auxiliares; atividades de vigilância e segurança privada; atividades de teleatendimento; coleta de resíduos; serviços de preparação; serviços especializados; suporte técnico; serviços de fornecimento de alimentação coletiva (catering); outras atividades de prestação de serviços. ${ }^{5}$

As variáveis utilizadas para traçar o perfil sociodemográfico e socioeconômico dos trabalhadores terceirizados foram:

Sexo: masculino e feminino.

Faixa etária: até 17 anos, de 18 a 24 anos, de 25 a 29 anos, de 30 a 39 anos, de 40 a 49 anos, de 50 a 64 anos, 65 anos ou mais.

Nível de instrução: sem instrução até Ensino Fundamental incompleto, Fundamental completo até Médio incompleto, Médio completo até Superior incompleto e Superior completo.

Tempo de emprego: menos de um ano, de um a menos de três anos, de três a menos de cinco anos, cinco anos ou mais e ignorado.

Rendimento médio em salário mínimo: até um salário, de um a dois salários mínimos, de dois a três salários mínimos, de três a cinco salários mínimos, de cinco a 10 salários mínimos, mais de 10 salários mínimos e ignorado.

Após a extração das variáveis anteriores, por meio de acesso on-line à base de dados da Rais e de tabulação em planilha de cálculo do Excel, os resultados foram analisados por meio de tabelas e gráficos, disponíveis na próxima seção.

\section{TRABALHADORES TERCEIRIZADOS NO MERCADO DE TRABALHO FORMAL BRASILEIRO}

No que concerne à evolução do número de trabalhadores terceirizados no mercado de trabalho formal brasileiro, o Gráfico 1 mostra que desde o primeiro ano de análise (2006) até o último (2018) houve um aumento de 4,5 milhões de postos de trabalho. Em 2006 havia 7,3 milhões de trabalhadores terceirizados com vínculo formal no país, e em 2018 eles eram 11,9 milhões. Apesar do aumento das vagas de trabalho terceirizado, na maioria dos casos elas eram marcadas por baixos rendimentos, elevada jornada de trabalho, alta rotatividade, instabilidade, insegurança, fragmentação sindical e desvalorização de classe, aspectos esses que ampliam as formas de precarização do trabalho (ANTUNES; DRUCK, 2015; CARVALHO; BRIDI, 2015).

\footnotetext{
5 Para consultar a lista completa das atividades classificadas como terceirizadas, ver Rebelo et al. (2018, p. 69-76).
} 


\section{GRÁFICO 1 - EVOLUÇÃO DO NÚMERO DE TRABALHADORES TERCEIRIZADOS NO MERCADO DE TRABALHO FORMAL - BRASIL, 2006-2018}

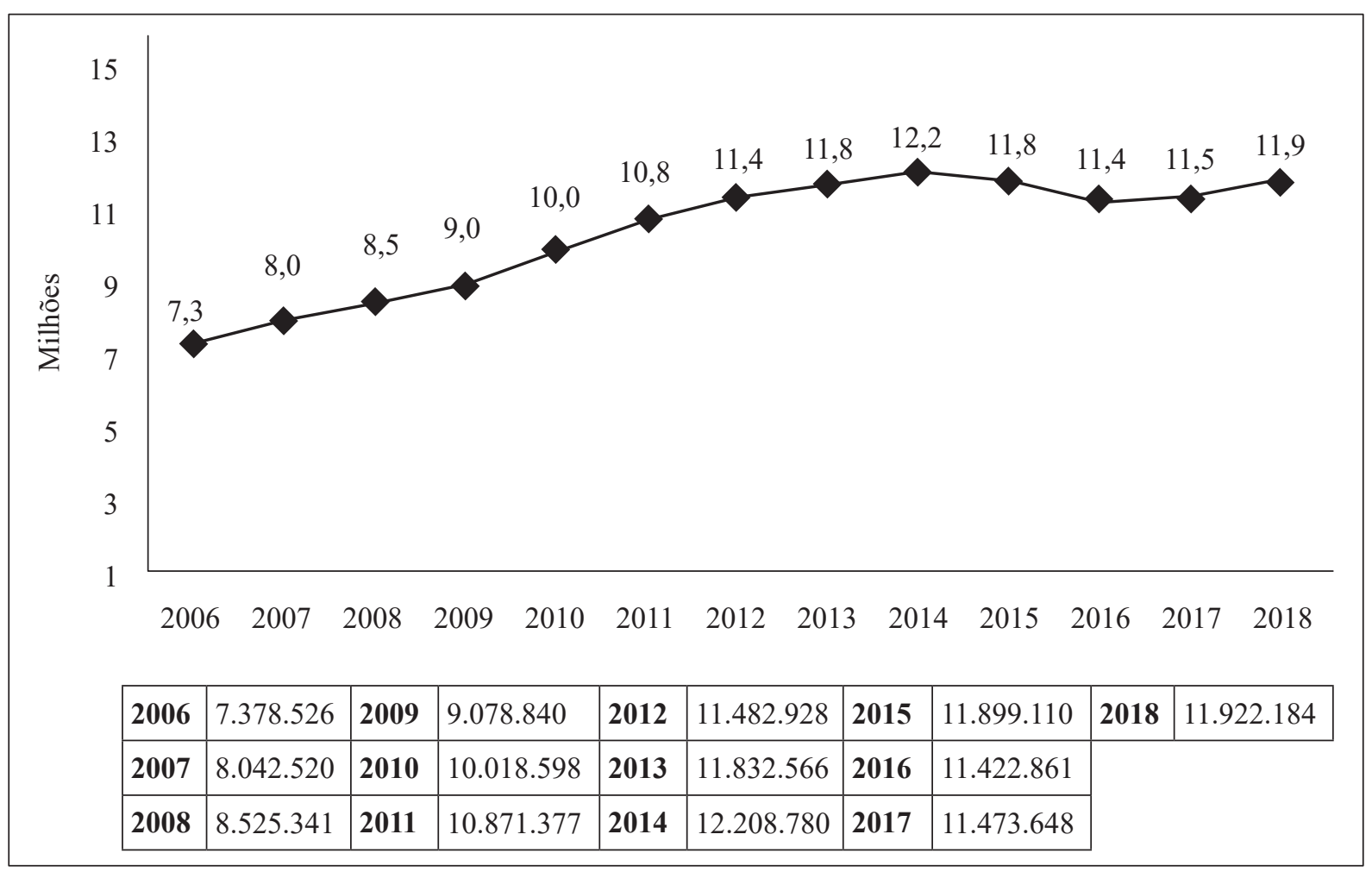

Fonte: RAIS, 2018.

Merece destaque, no ano de 2014, o ápice de contratações da categoria (12.208.780). Substancialmente, no próximo ano (2015) esse número se reduz para 11.899 .110 e diminui para 11.422.861 em 2016. O cenário macroeconômico explica notórias oscilações de aumento e declínio no número de trabalhadores terceirizados empregados formalmente. Em grande medida, decorrente das instabilidades do mercado de trabalho, ora mais propulsor e empregador da labuta terceirizada em momentos favoráveis de crescimento econômico - durante os períodos de 2006 a 2014 -, ora tendencioso ao desemprego e à contenção dos investimentos produtivos. Exemplo disso são os efeitos macroeconômicos da recessão econômica, iniciada no segundo trimestre de 2014 e com acirramento a partir de 2015, que ampliou a proporção de desempregados, desalentados e desocupados no país. Sem dúvidas, assim como ocorreu com os trabalhadores celetistas, a crise econômica afetou a geração de postos de trabalhos terceirizados, assim como possivelmente aumentou a transição para o desemprego e/ou a informalidade (BARBOSA, 2019; COSTA et al., 2019; POCHMANN, 2015).

Observa-se que nos últimos dois anos de análise (2017e2018) o número de trabalhadores terceirizados voltou a crescer, ainda que de modo inferior ao ano de 2014. Em 2017 havia 11.473.648 terceirizados com vínculo formal no país, e em 2018 esse volume aumentou para 11.922.184. Respectivo aumento do emprego terceirizado pode estar ligado à nova reforma trabalhista, sancionada no ano de 2017, por meio da Lei n. ${ }^{\circ} 13.429$, que caracteriza mudanças significativas no emprego terceirizado, porquanto permite a ampliação da terceirização para a função final/principal das instituições contratantes, ou seja, quaisquer atividades produtivas podem ser terceirizadas (CAMPOS, 2018a; MENDONÇA; ALESSI, 2017; PELATIERI et al., 2018b). A nova reforma trabalhista associada à crise econômica e política nos últimos anos, pode ter impulsionado o segmento do trabalho terceirizado no país. 
Os estudos argumentam que o projeto sancionado, além de permitir a terceirização desenfreada no país, amplia a flexibilização, a informalidade e a precarização do trabalho ao possibilitar que uma fração significativa dos trabalhadores celetistas seja convertida em terceirizados. Nesse sentido, a expansão das vagas terceirizadas não significa prestação de serviços qualificados e especializados. Ainda que a categoria de terceirizados seja um grupo bastante heterogêneo, a maioria dos postos de trabalho criados é precária, à medida que corresponde a atividades nas quais ocorre maior número de acidentes devido ao treinamento insuficiente. Além disso, a terceirização possibilita a fragmentação dos sindicatos, extensas jornadas de trabalho, a invisibilidade de classe e a burla dos direitos trabalhistas (ANTUNES, 2015; CAMPOS, 2015; 2018b; DRUCK et al., 2018; SEVERO, 2015; 2016).

\subsection{Perfil sociodemográfico}

No que diz respeito às características sociodemográficas dos trabalhadores terceirizados, a Tabela 1 mostra que em 2006 havia 7,3 milhões de terceirizados. Desse total, 4,6 milhões $(63,0 \%)$ eram do sexo masculino e 2,7 milhões $(37,0 \%)$ correspondiam à participação feminina. Em 2018, o número de postos de trabalho elevou-se para 11,9 milhões, dos quais 6,9 milhões $(58,7 \%)$ eram ocupados por homens e 4,9 milhões $(41,3 \%)$ por mulheres. Ademais, denota-se aumento da participação absoluta e relativa das mulheres, enquanto dos homens se pode observar perda da participação em termos relativos.

Isso decore da maior demanda do mercado por atividades de limpeza e conservação (setor de serviços), nas quais é possível verificar a massiva presença feminina. De maneira preliminar, essencialmente devido às desigualdades de gênero que ainda determinam as divisões ocupacionais no mercado de trabalho (DIEESE/CUT, 2011; IMHOFF; MORTARI, 2005).

TABELA 1 - TRABALHADORES TERCEIRIZADOS NO MERCADO DE TRABALHO FORMAL, SEGUNDO O SEXO - BRASIL, 2006-2018

\begin{tabular}{lccccc}
\hline \multirow{2}{*}{ Sexo } & \multicolumn{2}{c}{$\mathbf{2 0 0 6}$} & \multicolumn{2}{c}{$\mathbf{2 0 1 8}$} & \multicolumn{1}{c}{ Variação (\%) } \\
\cline { 2 - 6 } & $\mathbf{n .}^{\mathbf{0}}$ & $\mathbf{\%}$ & $\mathbf{n .}^{\mathbf{0}}$ & $\mathbf{\%}$ & $\mathbf{2 0 0 6 / 2 0 1 8}$ \\
\hline Masculino & 4.649 .265 & 63,0 & 6.998 .434 & 58,7 & 50,5 \\
\hline Feminino & 2.729 .261 & 37,0 & 4.923 .750 & 41,3 & 80,4 \\
\hline Total & 7.378 .526 & 100,0 & 11.922 .184 & 100,0 & 61,6 \\
\hline
\end{tabular}

Fonte: Rais, 2018.

Não obstante, no trabalho terceirizado que preza exclusivamente pela redução dos custos essa premissa não seria diferente, uma vez que as atividades tipicamente femininas estão relacionadas aos serviços domésticos e à comunicação, que exigem mais contato e interação humana, sensibilidade e persuasão, ao passo que aos homens são atribuídas ocupações que exigem força. Como a mão de obra feminina mais barata representa contingente de grande interesse, notadamente o setor de serviços demanda mais essas características, por isso denota vagas crescentes de emprego na categoria dos terceirizados (SOUZA, 2012).

Tal receptividade ao público feminino na labuta terceirizada resulta da cultura sexista imposta desde primórdios civilizatórios, que incumbe à mulher posição subalterna e ocupações de menor prestígio social, nas quais são demandadas as "qualidades femininas" (sensibilidade, afeto, delicadeza) que são recriadas nas atividades domésticas e no seio da família patriarcal (MELO, 1998; WAJNMAN, 2006). Possivelmente, isso explica o aumento da participação 
relativa das mulheres no trabalho terceirizado. Como corolário, fruto da chamada bipolaridade do mercado de trabalho, são gerados postos de trabalho essencialmente femininos, todavia, significativamente mais precários, mal remunerados e discriminatórios.

Quanto à idade, os resultados expostos no Gráfico 2 mostram que em ambos os anos de análise a maior parcela dos trabalhadores terceirizados tinha entre 30 a 39 anos de idade. Em 2006, 29,6\% dos terceirizados tinham respectiva faixa etária, e 2018 eles representavam 32,4\%. Isso indica o envelhecimento da mão de obra (pessoas que foram contratadas mais jovens e permaneceram no emprego com o passar dos anos). Provavelmente, isso pode estar relacionado com a experiência adquirida pelos trabalhadores, que acaba retendo o proletariado na mesma atividade, e/ou por falta de oportunidade de um trabalho melhor, seja pela baixa qualificação profissional, seja por acomodação e/ou medo desses profissionais de se arriscar no mercado de trabalho (SOUZA, 2012).

Chama atenção no Gráfico 2 que 30,2\% dos trabalhadores terceirizados formais apresentavam idades acima de 40 anos em 2006, e que em 2018 essa porcentagem aumentou para 37,4\%. Esses resultados refletem a preferência do segmento por trabalhadores com maior capacidade de adaptação e reprodução, ou seja, trabalhadores mais velhos que são direcionados para atividades "mais leves" (limpeza e conservação), que por sua vez demandam mais empregados com o fator experiência/idade.

\section{GRÁFICO 2 - DISTRIBUIÇÃO ETÁRIA DOS TRABALHADORES TERCEIRIZADOS NO MERCADO DE TRABALHO FORMAL - BRASIL, 2006-2018 (\%)}

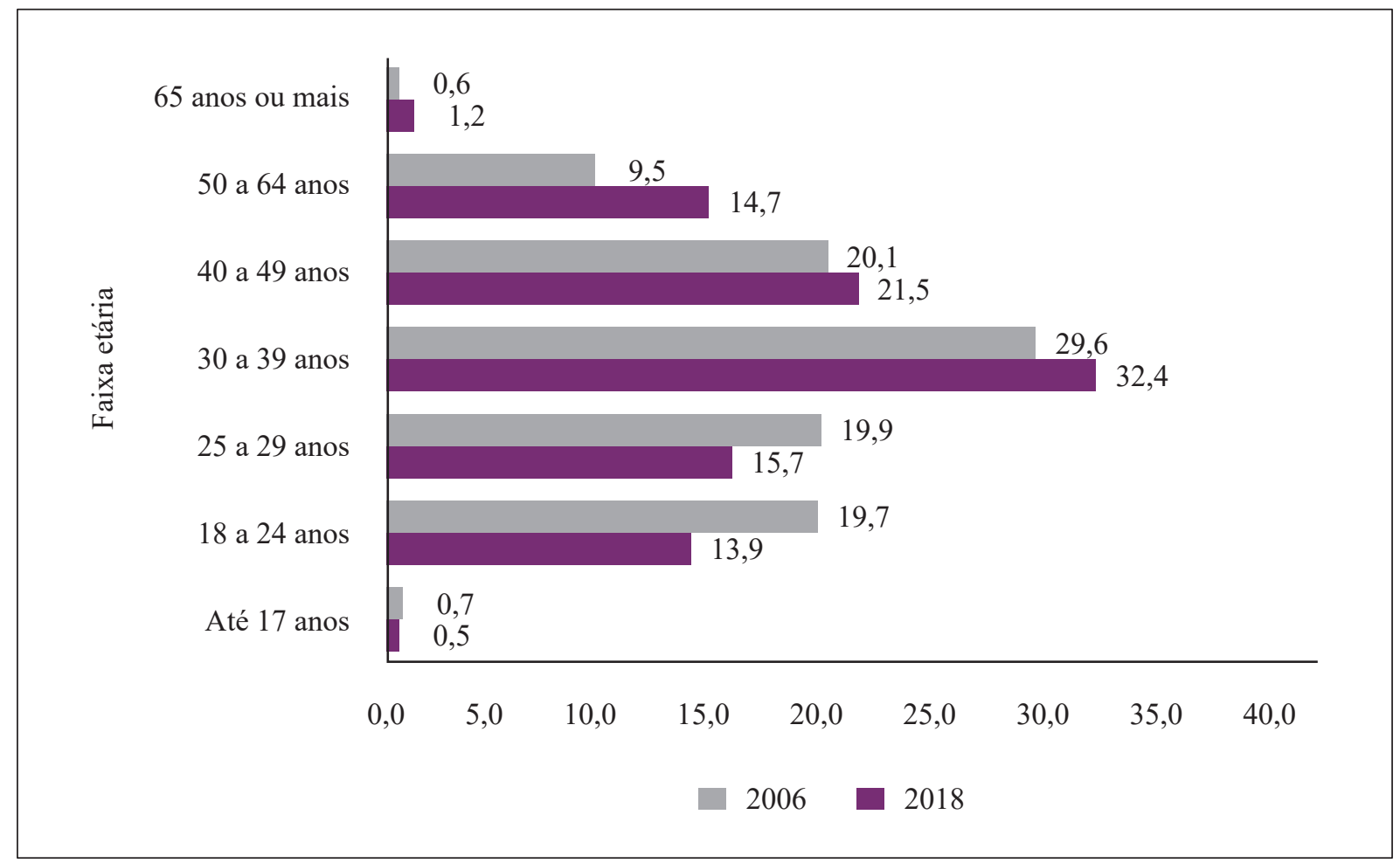

Fonte: Rais, 2018.

Todavia, é preciso mencionar que nas atividades de manutenção-que também envolvem as ocupações de limpeza e conservação - a terceirização cria uma classe de trabalhadores invisíveis, que exercem suas funções sem que os empregadores ao menos saibam seus nomes. Em um ambiente inóspito e facilitador da discriminação, os terceirizados são reduzidos à condição de "coisa invisível": comem em lugar diferente, têm uniformes diversificados e são 
excluídos dos direitos trabalhistas e da identidade coletiva. Na ânsia da redução dos custos, evitam-se os vínculos empregatícios e destrói-se a classe trabalhadora (SEVERO, 2015).

Nesse ensejo, merece destaque o aumento significante de trabalhadores terceirizados na faixa etária de 50 a 64 anos. Em 2006, 9,5\% dos ocupados concentravam-se em respectiva faixa etária, e no ano de 2018 esse número saltou para 14,7\%. Seguindo a mesma dinâmica das faixas anteriores (30 a 49 anos), nota-se no segmento a demanda por trabalhadores terceirizados com mais experiência, paciência e poder de adaptação, e que possam ainda proporcionar bons resultados, principalmente se for a baixo custo. Os trabalhadores com idades mais avançadas, por encontrar poucas oportunidades no mercado de trabalho e em prol da sobrevivência, optam por empregos mais precários, tais como os terceirizados. Outro fator preponderante para a concentração dessa população no setor é a redução da mortalidade e o aumento da expectativa de vida, que aumentou significativamente o "estoque" de trabalhadores (DEDECCA; CUNHA, 2004).

Considerando o nível de instrução dos trabalhadores terceirizados, a maioria tem o Ensino Médio completo até o Superior incompleto. Em 2006 esses eram 43,3\% do total de ocupados, aumentando para 56,5\% em 2018 (Gráfico 3). Isso se deve às políticas educacionais implementadas nos últimos anos no Brasil, visando à universalização do ensino na idade certa, à diminuição da evasão escolar, à correção das distorções de idade/série, à educação de jovens e adultos e à gestão escolar, que contribuíram significativamente para a melhoria educacional dos trabalhadores (POCHMANN, 2010).

\section{GRÁFICO 3 - DISTRIBUIÇÃO PERCENTUAL DE TRABALHADORES TERCEIRIZADOS NO MERCADO DE TRABALHO FORMAL, SEGUNDO NÍVEL DE INSTRUÇÃO - BRASIL, 2006-2018}

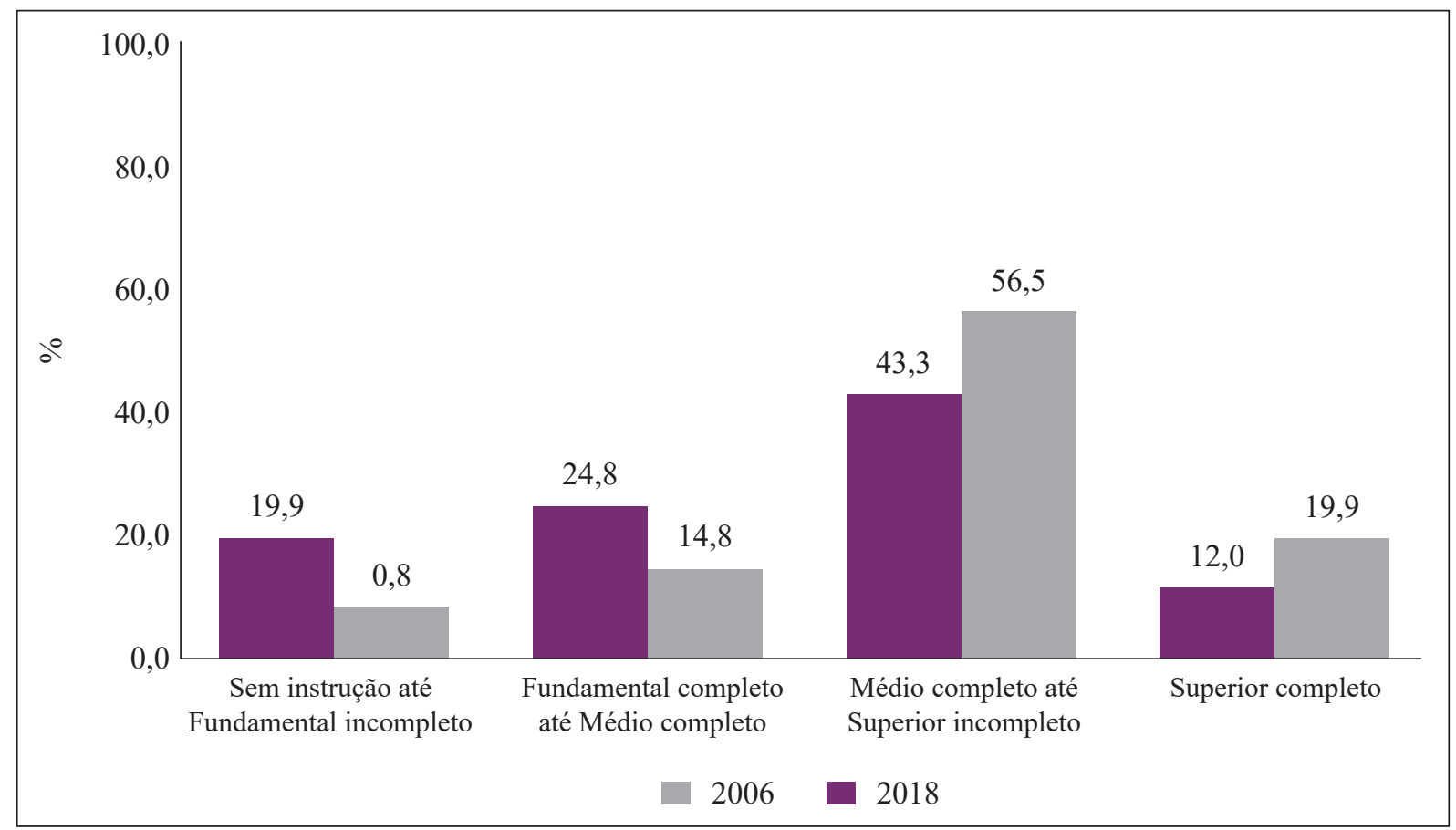

Fonte: Rais, 2018.

Com relação aos trabalhadores com Ensino Superior completo, chama atenção o aumento de terceirizados com respectivo nível de instrução no período em apreço. Em 2006, apenas $12 \%$ dos trabalhadores terceirizados formais tinham Ensino Superior completo. No ano 
de 2018, eles representavam cerca de $20 \%$ do total de ocupados. Claramente, esse resultado expressivo é fruto da demanda do setor por trabalhadores mais especializados e qualificados para serviços de apoio técnico, informática, contabilidade e jurídicos, áreas que estão em ascensão nos serviços terceirizados (IMHOFF; MORTARI, 2005).

É importante frisar que apesar da diminuição de trabalhadores terceirizados com baixo nível de instrução (sem instrução até Ensino Médio incompleto), nota-se que esse grupo supera o percentual de admitidos com escolaridade mais elevada (Superior completo) nos dois anos em análise. Fato é que ainda predominam no mercado de trabalho terceirizado empregados com pouca qualificação (Ensino Médio incompleto até Superior incompleto) para a prestação de serviços. Premissa que contraria a tese que os serviços realizados pelos empregados terceirizados seriam mais especializadas e eficazes do que os realizados internamente pelos funcionários contratados diretamente pelas organizações. Observa-se desse modo que a terceirização não é empregada para agilidade gerencial, mas para diminuição dos encargos trabalhistas.

Focalizando as condições de trabalho do setor de fertilizantes, Ribeiro (2004) afirma que em prol da redução de custos trabalhadores diretos das funções de apoio, por exemplo transporte e segurança, foram demitidos pelas instituições e contratados por prestadoras de serviço para atuarem no mesmo local e na mesma ocupação como terceirizados. Expressivamente, observou-se nessa transação piora das condições de trabalho, a saber: aumento da jornada de trabalho, acúmulo do volume de serviços, redução dos rendimentos, perda dos direitos assegurados e quebra da identidade coletiva. Como corolário, a labuta terceirizada constantemente contradiz suas premissas básicas e coloca em dúvida todo o processo, reafirmando nos resultados a fundamentação teórica daqueles que a caracterizam como precária.

\subsection{Perfil socioeconômico e ocupacional}

Referente ao tempo de emprego, a Tabela 2 ilustra que a maior parte dos trabalhadores terceirizados permaneceu menos de um ano no mesmo emprego. Em 2006, 39,3\% da labuta terceirizada concentrava-se nessa respectiva faixa; em 2018 a participação reduz para 35,5\%, mas permaneceu predominando com tempo de emprego de menos de um ano.

TABELA 2 - TRABALHADORES TERCEIRIZADOS NO MERCADO DE TRABALHO FORMAL, SEGUNDO TEMPO DE EMPREGO - BRASIL, 2006-2018

\begin{tabular}{lccccc}
\hline \multirow{2}{*}{ Tempo de emprego } & \multicolumn{2}{c}{$\mathbf{2 0 0 6}$} & \multicolumn{2}{c}{$\mathbf{2 0 1 8}$} & \multicolumn{2}{c}{ Variação (\%) } \\
\cline { 2 - 6 } & $\mathbf{n . ~}^{\mathbf{0}}$ & $\mathbf{( \% )}$ & $\mathbf{n .}^{\mathbf{0}}$ & $\mathbf{( \% )}$ & $\mathbf{2 0 0 6 / 2 0 1 8}$ \\
\hline Menos de 1 ano & 2.900 .155 & 39,3 & 4.236 .210 & 35,5 & 46,1 \\
\hline 1 a menos de 3 anos & 2.131 .371 & 28,9 & 3.238 .267 & 27,2 & 51,9 \\
\hline 3 a menos de 5 anos & 839.871 & 11,4 & 1.687 .051 & 14,2 & 100,9 \\
\hline 5 ou mais anos & 1.502 .872 & 20,4 & 2.753 .885 & 23,1 & 83,2 \\
\hline Ignorado & 4.257 & 0,1 & 6.771 & 0,1 & 59,1 \\
\hline Total & 7.378 .526 & 100,0 & 11.922 .184 & 100,0 & 61,6 \\
\hline
\end{tabular}

Fonte: Rais, 2018. 
Os trabalhadores terceirizados de "segunda categoria" no mercado de trabalho formal apresentam intensa rotatividade da força de trabalho. Isso porque a terceirização imputa maior descontinuidade contratual em função dos "contratos flexíveis", aqueles por tempo determinado, por tarefa (empreitada), tempo parcial e/ou por prestação de serviço. Há trabalhadores de paradas que a todo o momento precisam trocar de crachá e empresa, pois seu contrato venceu. Desse modo, muitos terceirizados não conseguem usufruir de férias remuneradas, porquanto a contingência e a insegurança no trabalho corroem as relações trabalhistas. Além disso, os baixos salários, a precária atuação dos sindicatos e formas de luta no segmento devido à heterogeneidade de classe e as políticas de desregulação do mercado de trabalho penalizam a categoria com crescente desemprego e maior instabilidade (ANTUNES, 2015; DRUCK; BORGES, 2002; DRUCK; GODINHO, 2003).

Merece destaque a categoria "um a menos de três anos", a segunda em termos absolutos e relativos no que tange ao tempo de emprego dos terceirizados. Observa-se que em 2006 2,1 milhões ou 28,9\% dos empregados se concentrava em respectiva faixa temporal e que em 2018 esse número saltou para 3,2 milhões ou 27,2\%. Isso decore da multiplicação dos contratos terceirizados de curta duração para o mesmo tomador. Significativamente, no setor público empresas constantemente mudam seu Cadastro Nacional de Pessoas Jurídicas (CNPJ) para poder prestar o mesmo serviço. Estudos evidenciam que desse modo o empregado perde sua identidade cultural e sua referência quanto a seu real empregador, o que aumenta as possibilidades de fraudes dos direitos trabalhistas (ANTUNES; DRUCK, 2013; 2015; CARMO, 2011; DRUCK; FILGUEIRAS, 2014; IMHOFF; MORTARI, 2005).

Sem dúvidas, isso decore da realidade perversa imposta pela terceirização. Como ressalta Severo, “[...] quando muda a empresa prestadora, 'zera' o contrato. A remuneração volta a ser a inicial e o tempo de serviço volta a ser contado do início” (2016, p. 4). Assim, os trabalhadores passam por várias prestadoras de serviços sem tirar férias, auferindo baixos rendimentos e em constante rotatividade.

Com o intuito de obter resultados mais robustos comparou-se o tempo de emprego dos terceirizados em relação ao dos trabalhadores não terceirizados ${ }^{6}$. Os achados mostram que enquanto a maior parcela $(35,5 \%)$ dos terceirizados permaneceu menos de um ano no mesmo emprego em 2018, no grupo de não terceirizados $(38,8 \%)$ o tempo de emprego era de cinco anos ou mais. Como corolário, esses resultados reafirmam o que a maioria dos estudos tem evidenciado: a prática da terceirização agudiza a precarização das condições de trabalho.

Pelatieri et al. (2018a) confirmam essa perspectiva. Em 2014, a taxa de rotatividade nas atividades terceirizadas foi o dobro da verificada nas demais atividades econômicas (tipicamente contratantes). Quanto ao tempo médio de emprego, os resultados mostraram que enquanto o vínculo de emprego nas atividades tipicamente terceirizadas durava em média dois anos e dez meses, nas tipicamente contratantes a duração média era de cinco anos e dez meses. Desse modo, constataram os autores que o fenômeno da terceirização é marcado por elevada rotatividade, indicador preocupante, à medida que representa novos custos de seleção e treinamento para os empregadores e para os trabalhadores se traduz em insegurança e risco de menores rendimentos e direitos.

No que concerne aos salários (Tabela 3), verifica-se que em 2006 aproximadamente $48,5 \%$ dos trabalhadores terceirizados recebiam de um a dois salários mínimos. Em 2018, esse

\footnotetext{
${ }^{6}$ Em 2006 havia 21.629.841 trabalhadores formais não terceirizados no país, dos quais 7.500.866, ou 34,7\%, tinham cinco anos ou mais no mesmo emprego. No ano de 2018, do total de 27.267.863 trabalhadores não terceirizados, 10.588 .296 , ou $38,8 \%$, tinham respectivo tempo de emprego.
} 
valor aumentou para 53,2\%. Notadamente, predomina na labuta terceirizada o emprego precário e mal remunerado. $\mathrm{O}$ resultado é a perda da identidade coletiva por parte dos funcionários, a fuga do emprego e o adoecimento físico e psíquico, sobretudo perante a cobrança de metas, extensa jornada de trabalho e acidentes corriqueiros. Além disso, na maioria dos casos os critérios adotados para o pagamento dos terceirizados não são claros, e estes quase nunca sabem quanto ganharão ao final do mês, tendo de recorrer a "bicos" para complementar a renda (SEVERO, 2015).

Nessa perspectiva, segundo alguns estudiosos ocorre redução do salário real pago à mão de obra terceirizada significativamente devido à "necessidade" de atender às exigências e aos limites de valores dos contratos das tomadoras. Propaga-se desse modo a piora nas condições de vida de milhares de trabalhadores, que instáveis emocional e financeiramente já não têm mais motivação para o trabalho (DRUCK; BORGES, 2002; DRUCK; GODINHO, 2003; HUME, 2009).

TABELA 3 - TRABALHADORES TERCEIRIZADOS NO MERCADO DE TRABALHO FORMAL, SEGUNDO RENDIMENTO EM SALÁRIO MÍNIMO - BRASIL, 2006-2018

\begin{tabular}{lrrrrc}
\hline \multirow{2}{*}{$\begin{array}{c}\text { Faixa de rendimento } \\
\text { em salário mínimo }\end{array}$} & \multicolumn{2}{c}{$\mathbf{2 0 0 6}$} & \multicolumn{2}{c}{$\mathbf{2 0 1 8}$} & Variação (\%) \\
\cline { 2 - 6 } Até 1 salário & $\mathbf{\mathbf { n } ^ { 0 }}$ & $\mathbf{( \% )}$ & $\mathbf{n .}^{\mathbf{0}}$ & $\mathbf{( \% )}$ & $\mathbf{2 0 0 6 - 2 0 1 8}$ \\
\hline 1 a 2 SM* & 306.924 & 4,2 & 568.318 & 4,8 & 85,2 \\
\hline 2 a 3 SM & 3.576 .811 & 48,5 & 6.339 .999 & 53,2 & 77,3 \\
\hline 3 a 5 SM & 1.439 .513 & 19,5 & 2.265 .393 & 19,0 & 57,4 \\
\hline 5 a 10 SM & 942.930 & 12,8 & 1.325 .986 & 11,1 & 40,6 \\
\hline Mais de 10 SM & 606.844 & 8,2 & 782.784 & 6,6 & 29,0 \\
\hline Ignorado & 420.249 & 5,7 & 431.903 & 3,6 & 2,8 \\
\hline Total & 85.255 & 1,2 & 207.801 & 1,7 & 143,7 \\
\hline
\end{tabular}

Fonte: Rais, 2018.

* Salário mínimo (SM).

Com relação às demais faixas salariais, houve queda na participação dos trabalhadores terceirizados que auferiam "bons rendimentos" e aumento nas categorias de subsistência (até dois salários mínimos). Já nas faixas mais elevadas (mais de 10 salários mínimos) a representatividade dos empregados terceirizados é pouco expressiva no total das categorias de rendimento: apenas 5,7\% dos terceirizados recebiam mais de 10 salários mínimos em 2006, e em 2018 esse número arrefeceu para 3,6\%.

Do exposto, ratifica-se que a terceirização penaliza as relações empregatícias. Em detrimento da redução de custos, os terceirizados são contratados com condições de trabalho e remuneração inferior, o que propaga a insegurança, a rotatividade e a exploração da mão de obra (ARAÚJO; APOLINÁRIO, 2015; CARVALHO; BRIDI, 2015). Os estudos sobre as condições de trabalho dos terceirizados no país enfatizam o abismo salarial entre estes e os contratados diretamente.

Segundo o estudo de Pelatieri et al. (2018a), enquanto a remuneração média dos trabalhadores formais tipicamente contratados foi de 2.639 reais em 2014, a dos tipicamente terceirizados com vínculo formal foi de 2.021 reais. Nesse ensejo, Sousa, Sobral e Macambira 
(2018) também evidenciaram as desvantagens salariais dos trabalhadores terceirizados. Os achados mostram que a média salarial destes representava $66,13 \%$ do salário recebido pelos trabalhadores não terceirizados no Brasil em 2015.

Em suma, os achados deste estudo mostraram que os trabalhadores terceirizados são majoritariamente do sexo masculino, têm entre 30 a 39 anos de idade, têm do Ensino Médio completo até o Superior incompleto, apresentam elevada rotatividade de emprego e recebem baixos rendimentos. Desse modo, denotamos que a precarização do trabalho não se resume a ter ou não carteira assinada, mas expressivamente se manifesta por meio de baixos rendimentos, jornada de trabalho indeterminada, rotatividade do emprego, fragmentação sindical, discriminação social e de direitos e, por fim, invisibilidade de classe. Nesse sentido, este estudo se soma a diferentes pesquisas sobre o tema, a exemplo de Carvalho e Bridi (2015), Dieese (2014), Pelatieri et al. (2018a; 2018b), Rebelo et al. (2018), entre outras, contextualizadas na revisão de literatura, na perspectiva de que a terceirização, tal como empregada atualmente no país, precariza as relações de trabalho.

\section{CONSIDERAÇÕES FINAIS}

Este estudo teve como principal objetivo traçar o perfil sociodemográfico e socioeconômico dos trabalhadores terceirizados no mercado de trabalho formal brasileiro durante os anos de 2006 e 2018. Para tanto, inicialmente se apresentou, por meio de diferentes perspectivas, os conceitos e definições da terceirização do trabalho. Posteriormente, fez-se uma contextualização da recente regulamentação do trabalho terceirizado no Brasil.

Desse modo, conforme diversos estudos, quando se contratam empresas terceiras para a prestação de serviços um leque de oportunidades se abre para concorrência e competitividade, refletindo em qualidade e preço dos serviços no mercado consumidor. Em contrapartida, do ponto de vista social, há quebra da relação de trabalho, perda de vínculos com os empregados e redução de acesso aos direitos e benefícios sociais. Por diversos aspectos discriminatórios, o trabalho terceirizado torna-se precário em relação aos trabalhos celetistas. Assim, constata-se na fundamentação teórica que a terceirização é uma medida substancialmente perigosa quando não empregada com cautela e planejamento adequado, pois sua principal característica é a destruição dos laços trabalhistas.

Com relação ao mercado de trabalho, os dados expostos revelam aumento no número de trabalhadores terceirizados formais entre 2006 e 2018. Nesse ensejo, merece destaque que a partir de 2017 o aumento dos empregos terceirizados possivelmente está relacionado à nova reforma trabalhista e associado à crise econômica e política ocorrida nos últimos anos, que em grande medida impulsionou o segmento de trabalho terceirizado no país.

Quanto às características dos ocupados na atividade principal, na maioria os empregos terceirizados são ocupados por indivíduos do sexo masculino, embora as vagas preenchidas por mulheres tenham aumentado ao longo do ínterim analisado. Outrossim, os resultados mostraram aproximação dos indicadores relativos de ocupação de homens e mulheres em maior proporção em 2018. De maneira preliminar devido às desigualdades de gênero que ainda determinam as divisões ocupacionais no mercado de trabalho e incubem a mulher de ocupações subalternas, nesse setor, tido como precário, as "oportunidades" para elas estão em alta.

Com relação às demais características sociodemográficas, a maioria dos trabalhadores terceirizados têm entre 30 a 39 anos de idade e têm do Ensino Médio completo até o Superior incompleto. Por sua vez, além do baixo nível de instrução, a maior parte dos trabalhadores 
terceirizados permanece menos de um ano no mesmo emprego, em função dos "contratos flexíveis" impostos por tarefa (empreitada), que aumentam a rotatividade do emprego.

No que concerne aos salários dos trabalhadores terceirizados, em 2018 a maioria recebeu entre um e dois salários mínimos. Ademais, houve expressiva queda na participação de trabalhadores terceirizados que auferiam "bons rendimentos" e demasiado aumento nos salários de subsistência. Notadamente, predomina na labuta terceirizada o emprego precário e mal remunerado.

Como corolário, o trabalho terceirizado corriqueiramente é sinônimo de redução de custos e competitividade para o empregador, mas também de baixos rendimentos, jornada de trabalho indeterminada, rotatividade do emprego, discriminação social e de direitos e, por fim, invisibilidade de classe para o empregado, que é rebaixado ao papel de ser inferior. Assim, representa uma modernidade que corrompe as condições de trabalho.

Em síntese, ao longo do período analisado foi constatado que a terceirização promove a precarização do trabalho e em grande medida também promove a reprodução das desigualdades sociais. Desse modo, evidencia-se que muito ainda precisa ser discutido e debatido, sobretudo perante estratégias tão ambíguas que norteiam a vida de milhares de trabalhadores. É preciso pensar e lutar por uma sociedade mais justa, que promova equidade social e de direitos para todos os trabalhadores.

\section{REFERÊNCIAS}

ANTUNES, Ricardo. A sociedade da terceirização total. Revista da ABET, v. 14, n. 1, p. 6-14, jan./jun. 2015.

ANTUNES, Ricardo; DRUCK, Graça. A terceirização como regra? Revista TST, Brasília, v. 79, n. 4, p. 214-231, out./dez. 2013.

A terceirização sem limites: a precarização do trabalho como regra. O Social em Questão, ano 18, n. 34, p. 19-40, 2015.

ARAÚJO, Igor José Santana de; APOLINÁRIO, Valdênia. A terceirização e a "agenda do trabalho decente" da OIT: reflexões a partir do Banco do Brasil S/A. Revista da ABET, v. 14, n. 1, p. 78-98, jan./jun. 2015.

BARBOSA, Rogério Jerônimo. Estagnação desigual: desemprego, desalento, informalidade e a distribuição da renda do trabalho no período recente (2012-2019). In: IPEA - Instituto de Pesquisa Econômica Aplicada. Mercado de trabalho: conjuntura e análise. Brasília: Ipea, out. 2019. p. 59-70.

BIAVASCHI, Magda Barros; TEIXEIRA, Marilane Oliveira. A terceirização e seu dinâmico processo de regulamentação no Brasil: limites e possibilidades. Revista da ABET, v. 14, n. 1, p. 37-61, jan./jun. 2015 .

BRASIL. Câmara dos Deputados. Projeto de Lei n. ${ }^{\circ}$ 4.302-E/1998. Altera dispositivos da Lei n. ${ }^{\circ} 6.019$, de 3 de janeiro de 1974, que dispõe sobre o trabalho temporário nas empresas urbanas e dá outras providências; e dispõe sobre as relações de trabalho na empresa de prestação de serviços a terceiros. Brasília, DF. 1998. Disponível em: http://www.camara.gov.br/proposicoesWeb/ prop_mostrarintegra?codteor $=1537011 \&$ filename $=$ Tramitacao-PL $+4302 / 1998$. Acesso em: 19 abr. 2017. 
. Câmara dos Deputados. Projeto de Lei n. ${ }^{0}$ 4.330/2004. Dispõe sobre os contratos de terceirização e as relações de trabalho deles decorrentes. Disponível em: http://www.camara. gov.br/proposicoesWeb/prop_mostrarintegra?codteor=1325350. Acesso em: 3 ago. 2018.

. Senado Federal. Projeto de Lei do Senado n. ${ }^{\mathbf{3}}$ 300/2015. Dispõe sobre os contratos de terceirização de mão de obra e as relações de trabalho deles decorrentes. Brasília, DF. 2015. Disponível em: https:/www.google.com.br/webhp?sourceid=chrome-instant\&ion=1\&espv= 2\&ie $=\mathrm{UTF} 8 \# \mathrm{q}=$ projeto $+\mathrm{de}+\mathrm{eli}+\mathrm{do}+$ senado $+\mathrm{n} \% \mathrm{C} 2 \% \mathrm{BA}+300,+\mathrm{de}+2015$. Acesso em: $10 \mathrm{fev}$. 2017.

BRISOLA, Simone Esteves; OLIVEIRA, Lourival José de. Trabalho terceirizado no direito brasileiro: sinônimo de modernidade? Unopar Científica: Ciências Jurídicas e Empresarias, Londrina, v. 9, n. 1, p. 25-32, mar. 2008.

CAMPOS, André Gambier. Efeitos da terceirização sobre a saúde e segurança no trabalho: estimativas com base nos afastamentos. In: CAMPOS, André Gambier (org.). Terceirização do trabalho no Brasil: novas e distintas perspectivas para o debate, Brasília: Ipea, 2018b. p. 187-217.

. O Projeto de Lei n. ${ }^{\circ}$ 4.330/2004 e a terceirização no Brasil. Mercado de Trabalho, Rio de Janeiro, v. 21, p. 75-84, out. 2015.

. A terceirização no Brasil e as distintas propostas de regulação. In: CAMPOS, André Gambier (org.). Terceirização do trabalho no Brasil: novas e distintas perspectivas para o debate. Brasília: Ipea, 2018a. p. 143-156.

CARMO, Júlio Bernardo do. Precarização do direito do trabalho: terceirização. Migalhas, 20 out. 2011. Disponível em: https://www.trt3.jus.br/download/artigos/pdf/283_precarizacao_ direito_trabalho.pdf. Acesso em: 15 out. 2016.

CARVALHO, Lucas Vinicius de; BRIDI, Maria Aparecida. Trabalho e desigualdade: a terceirização e seus efeitos sobre os trabalhadores. Revista da ABET, v. 14, n. 1, p. 99-113, jan./jun. 2015.

COSTA, Joana et al. Crise econômica e a transição do emprego doméstico no Brasil. In: IPEA - Instituto de Pesquisa Econômica Aplicada. Mercado de trabalho: conjuntura e análise. Brasília: Ipea, out. 2019. p. 47-57.

CUT - Central Única dos Trabalhadores. Terceirização e desenvolvimento: uma conta que não fecha. Dossiê acerca do impacto da terceirização sobre os trabalhadores e propostas para garantir a igualdade de direitos. Secretaria Nacional de Relações de Trabalho e Departamento Intersindical de Estatística e Estudos Socioeconômicos. São Paulo: Central Única dos Trabalhadores, 2014.

DEDECCA, Cláudio Salvadori; CUNHA, José Marcos Pinto da. Migração, trabalho e renda nos anos 90: o caso da RMSP. Revista Brasileira Estudos Populacionais, Campinas, v. 21, n. 1, p. 49-66, jan./jun. 2004.

DELGADO, Mauricio Godinho. Curso de Direito do Trabalho. 2. ed. São Paulo: LTr, 2003.

DIEESe - Departamento Intersindical de Estatísticas e Estudos Socioeconômicos. O processo de terceirização e seus efeitos sobre os trabalhadores no Brasil. São Paulo: DIEESE/CUT, 2003. Disponível em: http://ftp.medicina.ufmg.br/osat/arquivos/6-07082015.pdf. Acesso em: 20. fev. 2017. 
DIEESE/CUT. Terceirização e Desenvolvimento, uma conta que não fecha. São Paulo: DIEESE/CUT, 2011.Disponível em: http://www.sinttel.org.br/downloads/dossie_terceirizacao_ cut.pdf. Acesso em: 7 nov. 2016.

DRUCK, Graça. Resenha. In: ANTUNES, Ricardo (org.). Riqueza e miséria do trabalho no Brasil. Caderno CRH, Salvador, v. 20, n. 51, p. 529-530, set./dez. 2007.

DRUCK, Graça; BORGES, Ângela. Terceirização: balanço de uma década. Caderno CRH, Salvador, n. 37, p. 111-139, jul./dez. 2002.

DRUCK, Graça; FILGUEIRAS, Vitor. A epidemia da terceirização e a responsabilidade do STF. Revista TST, Brasília, v. 80, n. 3, p. 106-125, jul./set. 2014.

DRUCK, Graça; GODINHO, Luis Flávio Reis. Um mosaico de classe: a terceirização na RLAM e a pulverização dos sindicatos. In: ENCONTRO ANUAL DA ANPOCS, 27., 2003, Caxambu. Anais [...]. Caxambu, 2003.

DRUCK, Graça et al. A terceirização no serviço público: particularidades e implicações. In: CAMPOS, André Gambier (org.). Terceirização do trabalho no Brasil: novas e distintas perspectivas para o debate. Brasília: Ipea, 2018. p. 113-141.

FERNANDES, Jorge Ulisses Jacoby; LARA, Diva Belo. Terceirização no serviço público. Revista TCMRJ, Rio de Janeiro, n. 54, p. 3-8, mai. 2013.

FRÓES, Walter Luiz. Terceirização: uma abordagem estratégica. FACEF Pesquisa, Franca, v. 6, n. 2, p. 93-113, 2003.

GIOSA, Lívio. Terceirização: uma abordagem estratégica. 5. ed. São Paulo: Pioneira, 1997.

HUME, Myrcéa Aparecida Pedra. A terceirização no direito do trabalho. 2009. Monografia (Graduação em Direito) - Universidade do Vale do Itajaí, Itajaí, 2009.

IBGE - INSTITUTO BRASILEIRO DE GEOGRAFIA E ESTATÍISTICA/ CONCLA COMISSÃO NACIONAL DE CLASSIFICAÇÃO. Classificação Nacional de Atividades Econômicas. Versão 2. 2007. Disponível em: http://www.rthcontabilidade.com.br/v_2015/ conteudo/tabelas_anexos/cnae2.pdf. Acesso em: 2 abr. 2017.

IMHOFF, Márcia Morais; MORTARI, Aline Perico. Terceirização, vantagens e desvantagens para as empresas. Revista Eletrônica de Contabilidade, edição especial, jun. 2005. Disponível em: https://periodicos.ufsm.br/contabilidade/article/view/6219. Acesso em: 21 mar. 2017.

LIMA, Jacob Carlos. A terceirização e os trabalhadores: revisitando algumas questões. Cadernos de Psicologia Social do Trabalho, v. 13, n. 1, p. 17-26, 2010.

MARCELINO, Paula; CAVALCANTE, Sávio. Por uma definição de terceirização. Caderno CRH, Salvador, v. 25, n. 65, p. 331-346, mai./ago. 2012.

MEIRELES, Joab Araújo. Terceirização: avanços e retrocessos no serviço público. 2014. Monografia (Bacharelado em Direto) - Universidade Estadual da Paraíba, Guarabira, 2014.

MELO, Hildete Pereira de. O serviço doméstico remunerado no Brasil: de criadas a trabalhadoras. Texto para discussão n. ${ }^{\circ}$ 565. Rio de Janeiro: Ipea, 1998. p. 1-29. Disponível em: http://www.ipea.gov.br/portal/images/stories/PDFs/TDs/td_0565.pdf. Acesso em: 29 mar. 2019.

MENDONÇA, Heloísa; ALESSI, Gil. Câmara aprova terceirização para todas as atividades. Entenda o que muda. El País, São Paulo/Brasília, 23 mar. 2017. Disponível em: https://brasil. elpais.com/brasil/2017/03/21/politica/1490127891_298981.html. Acesso em: 18 abr. 2017. 
OLIVEIRA, Ana Lúcia Amaral de. Terceirização e satisfação com o trabalho. 2009. Dissertação (Mestrado) - Escola Brasileira de Administração Pública e de Empresas, Fundação Getúlio Vargas (FGV), Rio de Janeiro, 2009.

OLIVEIRA, Francisco Antônio de. Da terceirização e da flexibilização como estágios para a globalização. Revista do Instituto de Pesquisas e Estudos, Bauru, n. 21, p. 187-231, abr./jul. 1998.

PELATIERI, Patrícia et al. As desigualdades entre trabalhadores terceirizados e diretamente contratados: análise a partir dos resultados de negociações coletivas de categorias selecionadas. In: CAMPOS, André Gambier (org.). Terceirização do trabalho no Brasil: novas e distintas perspectivas para o debate. Brasília: Ipea, 2018b. p. 33-48.

Terceirização e precarização das condições de trabalho: condições de trabalho e remuneração em atividades tipicamente terceirizadas e contratantes. In: CAMPOS, André Gambier (org.). Terceirização do trabalho no Brasil: novas e distintas perspectivas para o debate. Brasília: Ipea, 2018a. p. 11-31.

POCHMANN, Marcio. Ajuste econômico e desemprego recente no Brasil metropolitano. Estudos Avançados, v. 29, n. 85, p. 7-19, 2015.

. Estrutura social no Brasil: mudanças recentes. Serviço Social \& Sociedade, São Paulo, n. 104, p. 637-649, out./dez. 2010.

RAIS - Relação Anual de Informações Sociais. Manual de Orientação. Ano-base 2016. Brasília: MTb, SPPE, DES, CGET, 2016.

REBELO, André Marques et al. Terceirização: o que os dados revelam sobre remuneração, jornada e acidentes de trabalho. In: CAMPOS, André Gambier (org.). Terceirização do trabalho no Brasil: novas e distintas perspectivas para o debate. Brasília: Ipea, 2018. p. 49-76.

RIBEIRO, Rosana. Terceirização no setor de fertilizante: impactos sobre os trabalhadores e os sindicatos. Revista da ABET, v. 4, n. 1, jan./jun. 2004.

RUSSO, Giuseppe Maria; LEITÃO, Sergio Proença. Terceirização: uma análise desconstrutivista. Organizações \& Sociedade, v. 13, n. 36, p. 107-123, jan./mar. 2006.

SEVERO, Valdete Souto. Terceirização: o perverso discurso do mal menor. Revista Síntese: Trabalhista e Previdenciária, São Paulo, v. 27, n. 322, p. 285-310, abr. 2016.

Terceirização: o perverso discurso do mal menor. 2015. Disponível em: http:// www.femargs.com.br/uploads/artigos/terceirizacao-o-perverso-discurso-do-mal-menor/ terceirizacao-o-perverso-discurso-do-mal-menor.pdf. Acesso em: 20 fev. 2017.

SILVA, Otavio Pinto e. As relações de trabalho e a nova competência da justiça do trabalho. Revista TST, Brasília, v. 71, n. 1, p. 227-239, jan./abr. 2005.

SILVA, Ricardo Margonari. Terceirização no setor público: contexto da terceirização no setor público brasileiro. 2012. Artigo. (Especialização em Administração Geral) - Universidade Paulista, São Paulo, 2012.

SOUSA, Elaine Cristian dos Santos et al. "Outsourcing" como ferramenta estratégica de gestão empresarial: situação de algumas empresas do Vale do Paraíba. Revista de Gestão \& Tecnologia, v. 1, n. 1, p. 50-71, dez. 2013. 
SOUSA, Fernando Pires de; SOBRAL, Fabio Maia; MACAMBIRA, Júnior. Terceirização no processo de acumulação capitalista, suas imbricações com as formas de trabalho produtivo e improdutivo e manifestações. In: CAMPOS, André Gambier (org.). Terceirização do trabalho no Brasil: novas e distintas perspectivas para o debate. Brasília: Ipea, 2018. p. 77-94.

SOUZA, Elaine Silva de. A "maquiagem" do trabalho formal: um estudo do trabalho das mulheres terceirizadas no setor de limpeza da Universidade Federal da Bahia. 2012. Dissertação (Mestrado em Ciências Sociais) - Universidade Federal da Bahia, Salvador-BA, 2012.

TCU - TRIBUNAL DE CONTAS DA UNIÃO. Desempenho da Economia Brasileira. Disponível em: http://www.tcu.gov.br/contasdogoverno. Acesso em: 20 abr. 2017.

WAJNMAN, Simone. Mulheres na sociedade e no mercado de trabalho brasileiro: avanços e entraves. In: PORTO, Marta (org.). Olhares femininos, mulheres brasileiras. Rio de Janeiro: X Brasil, 2006. p. 77-108.

Recebido em maio de 2019

Aceito em novembro de 2019 